\title{
Neoplastic risk for liver and colon in primary sclerosing cholangitis
}

\author{
Aiva Lundberg Båve, Annika Bergquist \\ Department of Medicine Huddinge, Karolinska Institutet, Stockholm S-141 86, Sweden. \\ Correspondence to: Dr. Aiva Lundberg Båve, Department of Upper GI Disease, Division of Hepatology, Karolinska University \\ Hospital Huddinge, Stockholm S-141 86, Sweden. E-mail: aiva.lundberg.bave@ki.se \\ How to cite this article: Lundberg Båve A, Bergquist A. Neoplastic risk for liver and colon in primary sclerosing cholangitis. \\ Hepatoma Res 2021;7:58. https://dx.doi.org/10.20517/2394-5079.2021.27
}

Received: 1 Mar 2021 First Decision: 6 Mar 2021 Revised: 18 May 2021 Accepted: 2 Jun 2021 First online: 9 Jun 2021

Academic Editors: Guang-Wen Cao, Annarosa Floreani Copy Editor: Yue-Yue Zhang Production Editor: Yue-Yue Zhang

\begin{abstract}
Primary sclerosing cholangitis (PSC) is a rare disease that may well be notified as a premalignant condition due to the increased cancer risk. The risk is highest for hepatobiliary cancer and increased by 28-398 times compared to the general population. When comorbidity with inflammatory bowel disease exists, the risk for colorectal cancer is increased 5-12 times and may even be higher after liver transplantation. The cancer risk estimates have decreased with time but vary according to study design. More recent population-based studies have approximated lower cancer risk than previous studies. Higher awareness and earlier detection of PSC together with increased surveillance over time may have influenced risk estimates. Surveillance for PSC patients is recommended for early tumor detection in both the liver and colon to enable curative treatment. The evidence for the efficacy of surveillance for early detection of hepatobiliary cancer is weak and an accepted common strategy worldwide is lacking. The high risk of hepatobiliary cancers has been confirmed repeatedly and future studies in PSC should focus on individualizing follow-up strategies and treatment.
\end{abstract}

Keywords: Epidemiology, inflammatory bowel disease, hepatobiliary cancer, cholangiocarcinoma, gallbladder cancer, hepatocellular carcinoma, pancreatic cancer, colorectal cancer

\section{INTRODUCTION}

Primary sclerosing cholangitis (PSC) is a rare chronic inflammatory disease of both intra- and extra-hepatic bile ducts. PSC can present at any time in life with a median age of diagnosis in the early 40 s. Recent 
population-based studies have estimated incidence and prevalence to $0.5-1.6$ and 6-32 per $100,000^{[1-3]}$. The clinical course of the disease is variable. PSC may be stable and asymptomatic for many years but can progress more rapidly to cirrhosis, liver failure, and development of cancer. Inflammatory bowel disease (IBD) is present in around $70 \%^{[1,4]}$ and represents a specific phenotype, PSC-IBD ${ }^{[5-7]}$.

PSC can be defined as a premalignant condition $^{[8,9]}$. The high cancer risk in PSC is well established and cancer is the most common cause of death ${ }^{[1,4,10]}$. The risk is highest for bile duct cancer, but increased risks for hepatocellular carcinoma (HCC), pancreatic cancer, and colorectal cancer (CRC) are also reported ${ }^{[2,11-13]}$. Cholangiocarcinoma (CCA) has an aggressive course and poor prognosis with a one-year mortality rate of up to $80 \%{ }^{[14]}$. However, in carefully selected patients where liver transplantation following neoadjuvant chemoradiation is performed, a $65 \%$ survival after five years is achieved ${ }^{[15,16]}$. Early tumor detection and identification of risk factors for tumor development is of great importance for the individual patient, and the risk of cancer carries a substantial psychological burden in PSC.

In this review, we aim to summarize the current knowledge on the risk of cancer in PSC with a special focus on the liver and gut.

\section{ASSESSMENT OF CANCER RISK IN PSC}

Assessment of cancer risk in PSC is challenging. Factors that contribute to the uncertainty of the actual risk are rarity and heterogeneity of the disease, the variable disease course, diagnostic difficulties to differentiate between benign and malignant biliary strictures, and lack of a specific diagnostic code for PSC.

The majority of studies derive from tertiary centers in western countries where smaller cohorts are retrospectively described. These settings constitute an increased risk for selection and referral bias with a chance of overestimating risks. Population-based studies are warranted for adequate risk estimation. In rare diseases, such as PSC, cases tend to cluster at specialized centers, which influences the detection rate, and true population-based settings are difficult to achieve. Hence, large mixed cohorts may be equally appropriate as a population-based setting.

Registry-based studies of cancer risk in PSC need to be evaluated with special attention. Some studies use the International Statistical Classification of Diseases and Related Health Problems (ICD) codes for PSC diagnosis, entailing risk for misclassification. Confirmation of PSC diagnosis by scrutinization of medical records improves diagnostic precision and study quality. The code for sclerosing cholangitis, K83.0A, in ICD 10 is more specific than in previous ICD versions, but it is still used for secondary causes of sclerosing cholangitis, and its specificity has not been validated in larger cohorts. To increase the specificity when defining PSC, some registry studies combine the diagnoses of cholangitis and IBD or combine ICD code(s) with PSC specific investigations ${ }^{[1,13]}$.

The natural history of PSC has changed over time ${ }^{[14]}$. Increased awareness entails earlier PSC diagnosis, increasing the risk of lead-time bias. Heterogeneity and different phenotypes of the disease also seem to affect cancer risk. Small duct PSC has consistently been reported to be associated with a lower risk of $\mathrm{CCA}^{[16,17]}$. A progression of small duct to large duct disease is however seen in about $12 \%$ over a mean follow-up time of almost nine years ${ }^{[17]}$. In addition, PSC with features of autoimmune hepatitis (overlap $\mathrm{AIH} / \mathrm{PSC}$ ) have been reported to have a lower cancer risk than large duct PSC ${ }^{[18,19]}$. Consensus regarding the definition of overlap AIH/PSC is lacking and makes the assessment of cancer risk ambiguous. PSC with IBD is associated with higher cancer risk in both liver and colon than PSC alone ${ }^{[13,19]}$. The impact of type of IBD is more uncertain, although PSC-UC is reported with higher CCA risk ${ }^{[19]}$. The influence of sex has also been 
discussed, where male sex seems to be associated with a higher risk of $\mathrm{CCA}^{[19]}$.

An underestimation of CCA risk may occur due to diagnostic problems in the already fibrotic and strictured biliary tree, especially with decreasing frequency of post-mortem autopsy investigations. Furthermore, liver transplantation for precancerous stages may reduce cancer incidence ${ }^{[20]}$.

\section{THE RISK OF HEPATOBILIARY CANCER}

The risk estimate for hepatobiliary cancers varies remarkably across studies. Risk assessment has been made with comparisons to both general and IBD populations. The highest risk estimates come from early tertiary center studies. A summary of the largest studies evaluating the risk of developing CCA, hepatobiliary cancer, or hepatopancreatobiliary cancer is shown in Table 1.

\section{Population-based studies}

The thus far largest population-based study covering cancer risk in PSC $(N=2588)$ is the national registry study from United Kingdom during $2004-2016$ by Trivedi et al ${ }^{[13]}$. PSC patients were identified from an IBD cohort, and the diagnosis of PSC was ascertained by the ICD 10 code for sclerosing cholangitis together with a code of a PSC-related procedure. Overall, 6.5\% developed CCA, corresponding to a risk increase of 28 times compared to IBD controls. Cancer incidence increased with age and was highest in individuals older than 60 years. This study is limited by only including PSC patients with IBD.

Two additional large population-based studies have also been published ${ }^{[1,2]}$. First, in the population-based study by Boonstra et al. ${ }^{[1]}$ from the Netherlands, including 590 PSC patients with a follow-up of more than seven years, $7 \%$ developed CCA, of whom $80 \%$ died within one year after cancer diagnosis. Older age was a risk factor for CCA, and a 398 -fold increased risk compared to the general population was found. Cumulative risk after 10, 20, and 30 years was $6 \%, 14 \%$, and 20\%, respectively. Second, a hospital-based registry study from Finland by Barner-Rasmussen et al. ${ }^{[2]}$, comprising nearly one third of the Finnish population, evaluated 580 PSC patients (1990-2015). PSC diagnosis was confirmed by reviewing medical records, and CCA was diagnosed in $4.5 \%$. The risk compared with the general population was sharply increased $\left(\right.$ SIR $=235,95 \%$ CI: 143-362), and the mean survival after CCA diagnosis was 1.8 years ${ }^{[2]}$.

\section{Non-population-based studies}

The largest non-population-based study was a joint effort within the International PSC Study Group, published by Weismüller et al. ${ }^{[19]}$ in 2017. More than 7000 PSC patients from mixed populations in western countries were studied. The 10- and 20-year cumulative incidences of hepatopancreatobiliary cancer were $11 \%$ and $20 \%$, respectively, which is higher than in the population-based studies. In line with populationbased studies, the incidence of cancer increased with age with the highest incidence detected in patients over 60 years. Cancer risks in different PSC phenotypes were compared, and features of autoimmune hepatitis and small duct PSC were associated with a lower risk for hepatobiliary malignancy ${ }^{[19]}$.

In a study from Sweden comprising 604 PSC patients (1970-1998), hepatobiliary malignancies were found in $13 \%$, with a high risk increase compared to the general population ( $\mathrm{SIR}=161,95 \% \mathrm{CI}$ : 120.3-210.1). After excluding the first year of PSC diagnosis, the incidence rate of hepatobiliary cancer was $1.5 \%$ per year ${ }^{[11]}$. An extension of this study has recently been performed, but not yet published, with additional PSC-patients ( $N$ $=1433)$ and follow-up time (1970-2016). In this updated cohort, compared to matched controls from the general population, the risk of hepatobiliary cancer was also sharply increased (HR $=120.3$, 95\% CI: 71.6202.1), with a cumulative incidence at 10,20 , and 30 years after diagnosis of 5\%, $13 \%$, and $25 \%$, respectively ${ }^{[21]}$. 
Table 1. Studies assessing the risk for cholangiocarcinoma, hepatobiliary cancer, or hepatopancreatobiliary cancer in patients with primary sclerosing cholangitis

\begin{tabular}{|c|c|c|c|c|c|c|c|}
\hline $\begin{array}{l}\text { No. PSC- } \\
\text { patients }\end{array}$ & Setting & $\begin{array}{l}\text { Study } \\
\text { population }\end{array}$ & $\begin{array}{l}\text { Control } \\
\text { group }\end{array}$ & $\begin{array}{l}\text { Study period } \\
\text { (Median follow- } \\
\text { up time in } \\
\text { years) }\end{array}$ & IBD & $\begin{array}{l}\text { Risk estimate } \\
(95 \% \mathrm{Cl})\end{array}$ & Ref. \\
\hline 7121 & Mixed & Multi-national & NA & $\begin{array}{l}1980-2010 \\
(7.2)\end{array}$ & $70 \%$ & $\begin{array}{l}\text { HR HPBC } \\
15.7(14.12-17.34)\end{array}$ & Weismuller et al. ${ }^{[19]} 2017$ \\
\hline 2588 & Population & $\begin{array}{l}\text { United } \\
\text { Kingdom }\end{array}$ & IBD-patients & $\begin{array}{l}2006-2016 \\
\text { (NA) }\end{array}$ & $100 \%$ & $\begin{array}{l}\text { HR CCA } \\
28.46 \\
\text { HR HCC } \\
21.0 \\
\text { HR PC } 5.26\end{array}$ & Trivedi et al. ${ }^{[13]} 2020$ \\
\hline 1432 & Mixed & Sweden & $\begin{array}{l}\text { General } \\
\text { population }\end{array}$ & $\begin{array}{l}1969-2016 \\
(15.9)\end{array}$ & $88 \%$ & $\begin{array}{l}\text { HR HBC } \\
120.9(72.0-203.1) \\
\text { HR PC } 8.0(3.2- \\
20.2)\end{array}$ & Lundberg Båve et al. ${ }^{[21]} 2021$ \\
\hline 604 & Mixed & Sweden & $\begin{array}{l}\text { General } \\
\text { population }\end{array}$ & $\begin{array}{l}1970-1998 \\
(5.7)\end{array}$ & $79 \%$ & $\begin{array}{l}\text { SIR HBC } \\
161(120.3-210.1) \\
\text { SIR PC 14.3 (4.7- } \\
33.4)\end{array}$ & Bergquist et al. ${ }^{[11]} 2002$ \\
\hline 590 & Population & Netherlands & $\begin{array}{l}\text { General } \\
\text { population } \\
\text { UC-patients } \\
\text { (CRC-risk) }\end{array}$ & $\begin{array}{l}2000-2011 \\
(7.7)\end{array}$ & $68 \%$ & $\begin{array}{l}\text { SIR CCA } \\
398(246-608)\end{array}$ & Boonstra et al. ${ }^{[1]} 2013$ \\
\hline 580 & Population & Finland & $\begin{array}{l}\text { General } \\
\text { population }\end{array}$ & $\begin{array}{l}1990-2015 \\
(N A)\end{array}$ & $68 \%$ & $\begin{array}{l}\text { SIR CCA } \\
235(143-362) \\
\text { SIR HCC } \\
21.6(4.45-63.1)\end{array}$ & Barner-Rasmussen et al. ${ }^{[2]} 2020$ \\
\hline 399 & Tertiary & United States & NA & $\begin{array}{l}2005-2013 \\
\left(9.4^{\star}\right)\end{array}$ & $100 \%$ & NA & Gulamhusein et al. ${ }^{[27]} 2016$ \\
\hline 394 & Tertiary & Europe & NA & $\begin{array}{l}\text { NA-1998 } \\
(4.7)\end{array}$ & $82 \%$ & NA & Boberg et al. ${ }^{[124]} 2002$ \\
\hline 370 & Tertiary & $\begin{array}{l}\text { United } \\
\text { Kingdom }\end{array}$ & NA & $\begin{array}{l}1981-2004 \\
(4.9)\end{array}$ & $85 \%$ ** & NA & Morris-Stiff et al. ${ }^{[125]} 2008$ \\
\hline 305 & Mixed & Sweden & NA & $\begin{array}{l}\text { NA-1992 } \\
(5.3)\end{array}$ & $81 \%$ & NA & Broomé et al. ${ }^{[28]} 1996$ \\
\hline 273 & Tertiary & Germany & NA & $\begin{array}{l}1978-2004 \\
(6.3)\end{array}$ & $63 \%$ & NA & Tischendorf et al. ${ }^{[10]} 2007$ \\
\hline 250 & Population & $\begin{array}{l}\text { United } \\
\text { Kingdom }\end{array}$ & $\begin{array}{l}\text { General } \\
\text { population }\end{array}$ & $\begin{array}{l}1998-2014 \\
(5.1)\end{array}$ & $54 \%$ & $\begin{array}{l}\text { IRR HBC } \\
65.3(9.5-2810.9)\end{array}$ & Liang et al. ${ }^{[3]} 2017$ \\
\hline 224 & Tertiary & United States & IBD patients & $(N A)$ & $100 \%$ & $\begin{array}{l}\text { OR CCA } \\
55.31(22.20- \\
137.80) \\
\text { OR PC } \\
11.22(4.11-30.62)\end{array}$ & Ananthakrishnan et al. ${ }^{[12]} 2014$ \\
\hline 223 & Population & $\begin{array}{l}\text { United } \\
\text { Kingdom }\end{array}$ & $\begin{array}{l}\text { General } \\
\text { population }\end{array}$ & $\begin{array}{l}1987-2002 \\
(N A)\end{array}$ & $48 \%$ & $\begin{array}{l}\text { HR HBC } \\
41.52(11.43- \\
150.80)\end{array}$ & Card et al. ${ }^{[70]} 2008$ \\
\hline 211 & Tertiary & Netherlands & NA & $\begin{array}{l}1980-2000 \\
(9 \text { years })\end{array}$ & $75 \%$ & $\begin{array}{l}\text { Cum Inc } \\
10 \text { years 9\% } \\
20 \text { years } 9 \%\end{array}$ & Claessen et al. ${ }^{[126]} 2009$ \\
\hline 201 & Population & United States & $\begin{array}{l}\text { General } \\
\text { population }\end{array}$ & $\begin{array}{l}\text { 1992-2013 } \\
\text { (NA) }\end{array}$ & NA & $\begin{array}{l}\text { OR HBC } \\
1.99(1.48-2.67)- \\
7.53(5.37- \\
10.57)^{\star \star \star \star}\end{array}$ & McGee et al. ${ }^{[127]} 2019$ \\
\hline 195 & Population & Denmark & IBD patients & $\begin{array}{l}1977-2001 \\
(7.4 \text { years })\end{array}$ & $100 \%$ & $\begin{array}{l}\text { HR CCA } \\
190(54.8-660)\end{array}$ & Sørensen et al. ${ }^{[68]} 2018$ \\
\hline 194 & Population & Sweden & $\begin{array}{l}\text { General } \\
\text { population }\end{array}$ & $1992-2005$ & $76 \%$ & $\begin{array}{l}\text { SIR CCA } \\
868(505-1390) \\
\text { SIR HBC } \\
177(110-271)\end{array}$ & de Valle et al. ${ }^{[4]} 2012$ \\
\hline 174 & Tertiary & United States & NA & $\begin{array}{l}1970-1986 \\
\left(6 \text { years }^{\star \star}\right)\end{array}$ & $71 \%$ & NA & Wiesner et al. ${ }^{[128]} 1989$ \\
\hline
\end{tabular}




\begin{tabular}{|c|c|c|c|c|c|c|c|}
\hline 161 & Tertiary & United States & $\begin{array}{l}\text { General } \\
\text { population }\end{array}$ & $\begin{array}{l}1970-1997 \\
(11.5 \text { years })\end{array}$ & NA & $\begin{array}{l}\text { RR CCA } \\
1560(780-2793)\end{array}$ & Burak et al. ${ }^{[34]} 2004$ \\
\hline 139 & Tertiary & United States & NA & $\begin{array}{l}\text { 1984-1997 } \\
\text { (13 years) }\end{array}$ & $\begin{array}{l}61 \%- \\
80 \% \text { - }\end{array}$ & $\begin{array}{l}\text { Cum inc } \\
10 \text { years 27\% }\end{array}$ & Ahrendt et al. ${ }^{[29]} 1999$ \\
\hline 128 & Tertiary & $\begin{array}{l}\text { United } \\
\text { Kingdom }\end{array}$ & NA & $\begin{array}{l}\text { 1984-2011 } \\
(9 \text { years })\end{array}$ & $72 \%$ & NA & Chapman et al. ${ }^{[30]} 2012$ \\
\hline 126 & Tertiary & $\begin{array}{l}\text { United } \\
\text { Kingdom }\end{array}$ & NA & $\begin{array}{l}1972-1989 \\
(5.8 \text { years })\end{array}$ & $67 \%$ & NA & Farrant et al. ${ }^{[129]} 1991$ \\
\hline 125 & Population & Sweden & NA & $\begin{array}{l}\text { 1964-1991 } \\
(10 \text { years) }\end{array}$ & $85 \%$ & $\begin{array}{l}\text { Cum risk } \\
10 \text { years } 11.2 \%\end{array}$ & Kornfeld et al. ${ }^{[31]} 1997$ \\
\hline
\end{tabular}

${ }^{\star}$ Mean; ${ }^{* *}$ of patients with CCA; ${ }^{* * *} 61 \%$ in non-CCA and $80 \%$ in CCA; ${ }^{* * *}$ estimate size depending on intra- or extrahepatic localization. PSC: Primary sclerosing cholangitis; IBD: inflammatory bowel disease; NA: not available; Cl: confidence interval; HR: hazard ratio; SIR: standardized incidence ratio; IRR: incidence rate ratio; OR: odds ratio; RR: relative risk; Cum inc: cumulative incidence; Cum risk: cumulative risk; CCA: cholangiocarcinoma; HBC: hepatobiliary cancer; HPBC: hepatopancreatobiliary cancer; PC: pancreatic cancer.

\section{Risk factors for CCA}

Several risk factors for development of CCA have been reported, as presented in Table 2. Older age (> 60 years), male sex, presence of a dominant stricture, and comorbidity with IBD along with raised bilirubin levels are the most consistent risk factors reported ${ }^{[1,10,11,13,19,22,23]}$. The importance of environmental factors for CCA development, such as smoking and alcohol, is less clear and has only been evaluated in a few studies $^{[24,25]}$. Symptoms, hepatomegaly, and raised bilirubin levels should increase the suspicion of a an underlying CCA since they are reported to be associated with neoplastic development.

An increased risk for hepatobiliary cancer in patients with colorectal cancer or dysplasia is reported ${ }^{[1,26,27]}$. The association was first described in the early study by Broomé et al ${ }^{[26]}$ where $70 \%$ of all cases of CCA also developed CRC. In the population-based study by Boonstra et al. ${ }^{[1]}$, CRC was a time-dependent risk factor for developing CCA (HR = 4.57, 95\%CI: 1.08-19.41); it was significant but with a very wide confidence interval, making generalizability difficult. The increased risk for both cancers in a sub-cohort of individuals raises suspicion of a genetic susceptibility.

Long duration of PSC does not seem to be a risk factor for CCA with up to $66 \%$ of CCA or hepatobiliary cancers diagnosed within the first year after PSC diagnosis ${ }^{[1,2,10,11,13,19,28-32]}$. This is likely an effect of length time bias or reverse causation, where the underlying disease shows no evident signs until symptoms of cancer appear. The yearly risk after the first year has been reported to be $0.5 \%-1.5 \%^{[11,33,34]}$. The median time from PSC diagnosis to development of hepatobiliary cancer has been appreciated to be 3-4 years (range: 0.8-21 years $)^{[33,35]}$. This estimation has been made in smaller cohorts with wide distributions of events.

\section{THE RISK OF GALLBLADDER CANCER}

Pathology of the gallbladder is a common finding in patients with PSC, with gallstones, sludge, chronic cholecystitis, and polyps occurring in near half of the patients during the disease cours ${ }^{[36,37]}$. Half of all gallbladder mass lesions have been found to be malignant, and the cancer risk increases with polyp size and seems highest in polyps more than $8 \mathrm{~mm}^{[36,38,39]}$. The risk for gallbladder cancer $(\mathrm{GBC})$ in PSC has been evaluated in a few studies. In population-based studies, the risk has been reported to be increased 9-fold in PSC-IBD compared to non-PSC-IBD patients in one study ${ }^{[13]}$, and, in another study, it was increased 78 times compared to the general population ${ }^{[2]}$.

\section{THE RISK OF HEPATOCELLULAR CANCER}

Patients with cirrhosis have an increased risk of developing HCC, and risk estimates depend on the underlying liver disease ${ }^{[40]}$. In PSC, the risk for HCC is lower than for CCA. A 20-fold increased risk for 
Table 2. Risk factors for cholangiocarcinoma, hepatobiliary cancer, and hepatopancreatobiliary cancer in patients with primary sclerosing cholangitis

\begin{tabular}{|c|c|c|c|}
\hline Risk factor & Increased risk for & Risk estimate $(95 \% \mathrm{Cl})$ & Ref. \\
\hline Male sex & $\mathrm{HPBC}$ & $N A, N A, N A$ & {$[10,13,19]$} \\
\hline $\mathrm{IBD}$ & HPBC & NA & [19] \\
\hline Ulcerative colitis & HPBC & NA & [19] \\
\hline Symptoms & $\mathrm{HBC}$ & $N A, N A$ & {$[10,28]$} \\
\hline Hepatomegaly & $\mathrm{HBC}$ & $\mathrm{HR}=2.4(1.6-3.6)$ & {$[10]$} \\
\hline Persistent elevated bilirubin & $\mathrm{HBC}$ & $\mathrm{HR}=2.9(2.9-1.9)$ & {$[10]$} \\
\hline Elevated bilirubin & $\mathrm{HBC}$ & $N A, N A$ & {$[10,28]$} \\
\hline Age at PSC diagnosis & CCA & HR $=1.02(1.00-1.04), N A, H R[p e r$ 10-year increase 1.26 (1.16-1.37)], NA & {$[1,11,13,27,28]$} \\
\hline Duration of IBD & CCA & $\mathrm{HR}=1.33(1.11-1.60), \mathrm{OR}=1.59(1.12-2.24)$ & {$[27,124]$} \\
\hline Mayo risk score & CCA & $\mathrm{RR}=1.8(1.0-3.1), \mathrm{NA}, \mathrm{NA}$ & {$[30,33,130]$} \\
\hline Variceal bleeding & CCA & $R R=24.2(3.3-67.1)$ & [33] \\
\hline $\mathrm{CRC} /$ dysplasia & CCA & $\mathrm{HR}=4.57(1.08-19.41), \mathrm{HR}=1.52(0.97-2.37), \mathrm{NA}$ & {$[1,26,27]$} \\
\hline Proctocolectomy & CCA & $\mathrm{RR}=4.43(1.29-15.2), \mathrm{HR}=1.53(1.05-2.22)$ & {$[27,33]$} \\
\hline Dominant stricture & CCA & $\mathrm{HR}=2.3(1.6-3.3), \mathrm{NA}, \mathrm{NA}$ & {$[10,23,30]$} \\
\hline High CA 19-9 & CCA & $N A, N A, N A$ & {$[24,25,30]$} \\
\hline Smoking & CCA & NA & {$[24]$} \\
\hline Alcohol & CCA & $\mathrm{OR}=2.95(1.04-8.3)$ & {$[25]$} \\
\hline
\end{tabular}

CA 19-9: Carbohydrate antigen; CCA: cholangiocarcinoma; CRC: colorectal cancer; HBC: hepatobiliary cancer; HPBC: hepatopancreatobiliary cancer; IBD: inflammatory bowel disease; PSC: primary sclerosing cholangitis.

HCC in comparison to controls is reported from two recent large population-based studies, however information on cirrhosis status was lacking ${ }^{[2,13]}[$ Table 1]. In one study of patients undergoing liver transplantation, $2 \%$ of the PSC patients were found to have HCC in their explanted liver in comparison to $6 \%$ in patients with other benign transplant indications ${ }^{[41]}$. In one study where cirrhosis in PSC was defined mainly by occurrence of esophageal varices, no cases of HCC were found during 292 patient years of followup, and a complete analysis of 140 transplants revealed no cases of $\mathrm{HCC}^{[42]}$. Longitudinal data from the United States of 830 PSC patients detected 20 (2.4\%) patients with HCC during a 9.5-year follow-up, which represented $22 \%$ of all hepatobiliary cancers. All HCC cases had late-stage PSC ${ }^{[43]}$. Judging from this evidence, the increased risk for HCC in PSC concerns only those who have developed cirrhosis.

\section{THE RISK OF PANCREAS CANCER}

The first paper describing increased risk for pancreatic cancer in PSC was published in 2002 by Bergquist et al ${ }^{[11]}$ and has since been confirmed by others ${ }^{[1,13,21]}$ with a risk increase estimated to be $3-14$ times higher than in the general population. In IBD cohorts, the risk for pancreatic cancer has been estimated to be 5-8 times higher for IBD-PSC with a decreasing risk with increasing age ${ }^{[13,44]}$. All studies take note of the enlarged risk of misclassifying distal cholangiocarcinoma for pancreatic cancer. Studies on specific risk factors for pancreatic cancer in PSC are lacking.

\section{SURVEILLANCE FOR EARLY DETECTION OF HEPATOBILIARY CANCER}

The high risk and poor prognosis of hepatobiliary malignancies warrants surveillance for early detection. In most centers, image diagnostics of liver and bile ducts, with or without the tumor marker CA 19-9, are performed at least yearly. Ultrasound and magnetic resonance imaging (MRI) with magnetic resonance cholangiopancreatography (MRCP) are the usual imaging methods of choice. MRI/MRCP is superior to ultrasound in evaluating strictures, biliary dilatation, bile duct wall thickening, and infiltrative lesions $s^{[20,45,46]}$, as well as for detecting early signs of malignancy ${ }^{[47]}$. 
Guidelines support surveillance, albeit evidence for a concrete surveillance strategy is limited and prospective studies of the cost-benefit are needed ${ }^{[20]}$. One large retrospective study from the Mayo Clinic has shown that annual surveillance [imaging with ultrasound, MRI, or computer tomography plus cancer associated antigen (CA) 19-9] was associated with a better survival ${ }^{[43]}$. Patients exposed to surveillance were diagnosed earlier and were available for curative treatment with liver transplantation. Five-year overall survival in this study was $68 \%$ in the surveillance and $20 \%$ in the non-surveillance group. A lower probability of cancer related adverse events was also found at five-year follow-up ${ }^{[43]}$.

In another large study from the $\mathrm{UK}^{[13]}$, a 2 -fold reduced risk of cancer related death was associated with annual imaging before cancer diagnosis. The survival benefit after cancer diagnosis disappeared when CCA cases from the first year after PSC diagnosis were excluded. The main benefit from regular surveillance therefore seems to be generated by the early detection of HCC and GBC. Liver transplantation before an overt CCA in non-cirrhotic patients with precancerous stages (high-grade dysplasia) may be beneficial and is recommended in some countries ${ }^{[48,49]}$ with posttransplant survival similar to that after liver transplantation due to liver failure ${ }^{[50]}$. In summary, the efficacy of regular surveillance with imaging for early detection of CCA remains to be proven.

The tumor marker CA 19-9 is widely used for surveillance purposes. However, CA 19-9 lacks both sensitivity and specificity, and there is no tumor specific cut-off leve ${ }^{[51-55]}$. Longitudinal series with repeated measures of CA 19-9 are contradictory ${ }^{[52,56]}$ and increased levels are common in benign disease ${ }^{[54]}$. Normal levels are also frequently seen in patients with CCA. A low intraindividual variability of CA 19-9 over time is reported and the individual levels seem to be affected by genetic differences in the FUT 2/3 genes ${ }^{[56,57]}$. CA 19-9 was evaluated together with imaging in a surveillance program and was found to be a predictor of mortality and CCA-related adverse events, but $70 \%$ of the perihilar CCA in this study had low $(<100 \mathrm{U} / \mathrm{mL})$ or normal CA 19-9 level ${ }^{[43]}$. CA 19-9 is therefore an insufficient marker for regular surveillance for early detection of CCA in PSC ${ }^{[2,55-58]}$.

Due to the high risk of cancer development in gallbladder polyps, current guidelines recommend cholecystectomy in individuals where polyp size is more than $10 \mathrm{~mm}^{[59]}$. Cholecystectomy has been suggested to be performed in PSC patients with any polyp size due to the increased malignant potential of smaller lesions ${ }^{[36,39]}$, which is supported by current guidelines ${ }^{[20,60,61]}$. The malignant potential in smaller polyps has recently been questioned in a study of 453 PSC patients where 16\% developed smaller gallbladder polyps over 7.7 years and the majority were benign and did not increase in size over time. In most of these patients, a cholecystectomy was not performed, and polyps did not grow significantly over time, suggesting a wait and watch strategy ${ }^{[37]}$. The increased risk for GBC warrants annual screening and cholecystectomy should be performed if polyps are repeatedly found or increasing in size with consideration of surgical risk in more advanced PSC.

\section{THE RISK OF COLORECTAL CANCER}

IBD is present in around 70\% of all PSC patients ${ }^{[1,4]}$. The most common subtype is ulcerative colitis (UC), although typical features in PSC patients indicate a unique phenotype ${ }^{[5,6,7]}$. Given the dominant localization of inflammation in the ascending colon, IBD in PSC is often less symptomatic, which is why chronic inflammation may go undetected ${ }^{[62,63]}$ and diagnosis be delayed. Frequent surveillance in PSC-IBD may affect risk estimates for CRC since PSC-IBD patients are surveilled to a higher extent than IBD alone ${ }^{[64]}$.

In studies of PSC patients with and without IBD, the risk of CRC has been appreciated to be 5-12 times higher compared to the general population ${ }^{[1,2,11]}$. Estimation of the risk of CRC in PSC-IBD has been done in 
two meta-analyses ${ }^{[65,66]}$ where the first found a nearly 5 -fold increased risk compared to non-PSC IBD $(\mathrm{OR}=$ 4.79, 95\%CI: 3.58-6.41) ${ }^{[65]}$, whereas the more recent showed a 3 -fold increased risk of CRC/dysplasia compared with patients with IBD alone (OR of 3.24, 95\%CI: 2.14-4.90) $)^{[6]]}$. Table 3 summarizes the most important studies evaluating risk of colorectal cancer in PSC.

Early studies show a high cumulative incidence of CRC in PSC-IBD, up to $40 \%$ after 20 years of PSC-IBD disease ${ }^{[67]}$. The CRC incidence rates seem to have decreased over time. Data from more recent studies, such as the population-based study by Boonstra et al. ${ }^{[1]}$ from 2013, show that $3 \%$ of PSC-IBD patients developed $\mathrm{CRC}$ at 7-year follow-up and the cumulative risk of high-grade dysplasia or CRC after 10, 20, and 30 years since PSC diagnosis was 3\%,7\%, and 13\%, respectively. In the study by Sorensen et al ${ }^{[68]}$ from $2018,7 \%$ and 9\% developed CRC at 10 and 20 years, respectively. Risk estimates often include CRC and both high- and low-grade dysplasia (LGD). This imposes a potential risk of misclassification bias as the assessment of LGD is precarious and embossed by interpersonal interpretation ${ }^{[69]}$.

Despite the well-established increased risk for CRC in PSC-IBD, some studies show conflicting results. Three population-based studies ${ }^{[3,4,70]}$ and two tertiary center studies ${ }^{[6,71]}$ have not shown increased CRC risk in PSC-IBD.

\section{Risk factors for CRC in PSC}

Age is associated with the increased CRC risk in PSC-IBD. In the study by Trivedi et al. ${ }^{[13]}$, the CRC risk was 5 -fold increased if IBD was diagnosed at an age $<50$ and only 2 -fold at ages 50-60. CRC also seems to develop at a younger age in PSC-IBD than in non-PSC-IBD. This was illustrated in the study by Boonstra et al. ${ }^{[1]}$, where median age at diagnosis of CRC in PSC-IBD was 39 (range: 26-64) compared to 59 (range: $34-73)$ in IBD controls.

The importance of IBD subtype for the risk of CRC has been discussed in PSC-IBD. Even though it is accepted that IBD in PSC is a phenotype of its own ${ }^{[6]}$, most studies show a higher risk for patients with PSCUC than with PSC and Crohn's disease. There have been several studies showing diverging results evaluating risk of CRC in PSC patients with Crohn's disease, where some show increased risk ${ }^{[37,72]}$ and some do $\operatorname{not}^{[71,73,74]}$.

The impact of chronic inflammation on the risk for CRC in PSC is unknown. Increased prevalence of rightsided colon cancers where inflammation generally is dominating in PSC supports that chronic inflammation may be important ${ }^{[75]}$. Previous studies have defined the PSC-IBD phenotype as mild, and early studies show less need of medical treatment ${ }^{[5,7,7,7]}$. However, a recent study showed similar need for treatment in PSC-IBD and non-PSC-IBD, and active inflammation was shown to be an independent risk factor for CRC in PSC-IBD (HR = 2.39, 95\%CI: 1.63-3.49) ${ }^{[64]}$. Other suggested mechanisms than chronic inflammation for malignant development likely involve altered bile composition and colonic microbiome ${ }^{[78,79]}$.

\section{Colorectal cancer risk after liver transplantation}

The risk of colonic neoplasia persists and may even escalate after liver transplantation.

A few studies have reported on the high CRC risk in posttransplant PSC-IBD ${ }^{[00-83]}$. The largest study comes from the Nordic countries where colorectal dysplasia or cancer developed in $23 \%$ with a median five-year (range: 0-21 years) follow-up after transplantation ${ }^{[83]}$. A meta-analysis from 2013 averaged a 10 times higher risk compared to individuals undergoing liver transplantation for reasons other than $\mathrm{PSC}^{[84]}$. 
Table 3. Articles stating risk for colorectal cancer in patients with primary sclerosing cholangitis

\begin{tabular}{|c|c|c|c|c|c|c|c|}
\hline $\begin{array}{l}\text { No. PSC- } \\
\text { patients }\end{array}$ & Setting & $\begin{array}{l}\text { Study } \\
\text { population }\end{array}$ & Control group & $\begin{array}{l}\text { Study period (Median follow-up time in } \\
\text { years) }\end{array}$ & IBD & $\begin{array}{l}\text { Risk estimate } \\
(95 \% \mathrm{Cl})\end{array}$ & Ref. \\
\hline 6268 & Population & Denmark & General population/IBD patients & $\begin{array}{l}1979-2008 \\
(\mathrm{NA})\end{array}$ & $100 \%$ & $\begin{array}{l}\text { RR UC } 9.13(4.52-18.5) \\
\text { CD } 2.90(0.40-20.9)\end{array}$ & Jess et al. ${ }^{[131]} 2012$ \\
\hline 2588 & Population & United Kingdom & IBD patients & $\begin{array}{l}2006-2016 \\
(N A)\end{array}$ & $100 \%$ & $\mathrm{HR}=2.43(\mathrm{NA})$ & Trivedi et al. ${ }^{[13]} 2020$ \\
\hline 1432 & Mixed & Sweden & General population & $\begin{array}{l}1969-2016 \\
(15.9)\end{array}$ & $88 \%$ & $\mathrm{HR}=7.5(5.6-10.0)$ & Lundberg Båve et al. ${ }^{[21]} 2021$ \\
\hline 1022 & $\begin{array}{l}\text { Meta- } \\
\text { analysis }\end{array}$ & $\begin{array}{l}\text { United States } \\
\text { Argentina } \\
\text { Europe }\end{array}$ & NA & $\begin{array}{l}1992-2015^{\star \star *} \\
(N A)\end{array}$ & NA & $\mathrm{OR}=3.24(2.14-4.90)$ & Zheng et al. ${ }^{[66]} 2016$ \\
\hline 604 & Mixed & Sweden & General population & $\begin{array}{l}1970-1998 \\
(5.7)\end{array}$ & $79 \%$ & $\mathrm{SIR}=10.3(5.3-18.1)$ & Bergquist et al. ${ }^{[11]} 2002$ \\
\hline 590 & Population & Netherlands & $\begin{array}{l}\text { General population and UC- } \\
\text { patients }\end{array}$ & $\begin{array}{l}2000-2011 \\
(7.7)\end{array}$ & $68 \%$ & $\mathrm{SIR}=5(2.02-10.5)$ & Boonstra et al. ${ }^{[1]} 2013$ \\
\hline 580 & Population & Finland & General population & $\begin{array}{l}1990-2015 \\
(N A)\end{array}$ & $68 \%$ & $\begin{array}{l}\text { SIR } \\
\text { Colon } 5.2(1.7-12.2) \\
\text { Rectum } 5.0(1.0-14.7)\end{array}$ & $\begin{array}{l}\text { Barner-Rasmussen et al. }{ }^{[2]} \\
2020\end{array}$ \\
\hline 564 & $\begin{array}{l}\text { Meta- } \\
\text { analysis }\end{array}$ & $\begin{array}{l}\text { United States } \\
\text { Europe }\end{array}$ & NA & $\begin{array}{l}1992-1999^{\star \star \star} \\
(N A)\end{array}$ & NA & $\mathrm{OR}=4.79(3.58-6.41)$ & Soetniko et al. ${ }^{[65]} 2002$ \\
\hline 293 & Mixed & $\begin{array}{l}\text { Netherlands } \\
\text { United States }\end{array}$ & IBD patients & $\begin{array}{l}2000-2015 \\
\left(4.1^{\star}\right)\end{array}$ & $100 \%$ & $\mathrm{IRR}=2.2(\mathrm{NA})$ & Shah et al. ${ }^{[64]} 2018$ \\
\hline 277 & Mixed & Spain & IBD patients & $\begin{array}{l}2006-2018 \\
(13.6)\end{array}$ & $100 \%$ & $\begin{array}{l}\mathrm{IR}=3.3 / 1000 \text { patient } \\
\text { years }\end{array}$ & Guerra et al. ${ }^{[132]} 2019$ \\
\hline 250 & Population & United Kingdom & General population & $\begin{array}{l}1998-2014 \\
(5.1)\end{array}$ & $54 \%$ & $\mathrm{IRR}=2.5(0.8-7.0)$ & Liang et al. ${ }^{[3]} 2017$ \\
\hline 224 & Tertiary & United States & IBD patients & $(N A)$ & $100 \%$ & $\mathrm{OR}=5.00(2.80-8.95)$ & Ananthakrishnan et al. ${ }^{[12]} 2014$ \\
\hline 223 & Population & United Kingdom & General population & $\begin{array}{l}1987-2002 \\
(N A)\end{array}$ & $48 \%$ & $\mathrm{HR}^{\star \star}=2.53(0.95-6.74)$ & Card et al. ${ }^{[70]} 2008$ \\
\hline 211 & Tertiary & Netherlands & NA & $\begin{array}{l}1980-2000 \\
(9)\end{array}$ & $75 \%$ & $\begin{array}{l}\text { Cum Inc } \\
10 \text { years } 9 \% \\
20 \text { years } 22 \%\end{array}$ & Claessen et al. ${ }^{[126]} 2009$ \\
\hline 200 & Tertiary & Belgium & NA & $\begin{array}{l}\text { NA-2009 } \\
\text { (11) }\end{array}$ & $60 \%$ & $\begin{array}{l}\text { Cum risk } \\
10 \text { years } 5.41 \% \\
20 \text { years } 9.27 \%\end{array}$ & Fevery et al. ${ }^{[35]} 2012$ \\
\hline 195 & Population & Denmark & IBD patients & $\begin{array}{l}1977-2011 \\
(7.4)\end{array}$ & $100 \%$ & $H R=21.4(9.6-47.6)$ & Sørensen et al. ${ }^{[68]} 2018$ \\
\hline 194 & Population & Sweden & General population & $\begin{array}{l}1992-2005 \\
(6.5)\end{array}$ & $76 \%$ & $H R=2.87(0.33-10.4)$ & De Valle et al. ${ }^{[4]} 2012$ \\
\hline
\end{tabular}




\begin{tabular}{|c|c|c|c|c|c|c|c|}
\hline 166 & Tertiary & United Kingdom & IBD patients & NA & $100 \%$ & $\begin{array}{l}\text { OR UC-PSC } \\
2.7(0.7-10.1)\end{array}$ & Braden et al. ${ }^{[71]} 2012$ \\
\hline 132 & Tertiary & United States & UC patients & $\begin{array}{l}1976-1994 \\
\text { (NA) }\end{array}$ & $100 \%$ & $\begin{array}{l}\text { RR CRN } \\
3.15(1.4-7.3)\end{array}$ & Shetty et al. ${ }^{[75]} 1999$ \\
\hline 125 & Population & Sweden & NA & $\begin{array}{l}\text { 1964-1991 } \\
(10)\end{array}$ & $85 \%$ & $\begin{array}{l}\text { Cum risk } \\
10 \text { years } 16 \%\end{array}$ & Kornfeld et al. ${ }^{[67]} 1997$ \\
\hline 75 & Tertiary & France & IBD patients & $\begin{array}{l}\text { NA-2008 } \\
(11.1)\end{array}$ & $100 \%$ & $\begin{array}{l}\text { Cum inc } \\
25 \text { years } 23.4 \%\end{array}$ & Sokol et al. ${ }^{[133]} 2008$ \\
\hline 56 & Population & United States & NA & $\begin{array}{l}1976-2018 \\
(9.7)\end{array}$ & $75 \%$ & $\begin{array}{l}\text { Cum inc } \\
5 \text { years } 5.67 \% \\
10 \text { years } 9.77 \%\end{array}$ & Bakhshi et al. ${ }^{[32]} 2020$ \\
\hline 39 & Tertiary & Argentina & UC patients & $\begin{array}{l}\text { NA } \\
(8.5)\end{array}$ & $100 \%$ & $\begin{array}{l}\text { Cum Inc } \\
10 \text { years } 11 \% \\
20 \text { years } 18 \%\end{array}$ & Terg et al. ${ }^{[134]} 2008$ \\
\hline
\end{tabular}

${ }^{*}$ Mean; ${ }^{* *} \mathrm{GI}$ cancer; ${ }^{* * *}$ publication year of articles included. PSC: Primary sclerosing cholangitis; IBD: inflammatory bowel disease; UC: ulcerative colitis; CD: Crohn's disease; GI: gastrointestinal; NA: not available; CI: confidence interval; HR: hazard ratio; SIR: standardized incidence ratio; IR: incidence rate; IRR: incidence rate ratio; OR: odds ratio; RR: relative risk; Cum inc: cumulative incidence; Cum risk: cumulative risk; CRC: colorectal cancer; CRN: colorectal neoplasia.

\section{Surveillance for CRC}

The risk assessment for CRC in IBD is changing and affects follow-up strategies. Duration of IBD has up to recently been the leading measure, and patients with longstanding disease have been included in regular colonoscopy surveillance programs. Recent studies suggest that more attention should be drawn to other risk factors such as presence of a first degree relative with CRC $<50$ years of age, active inflammation, strictures, or inflammatory polyps ${ }^{[74,85-91]}$. An index colonoscopy for CRC risk assessment is now recommended in non-PSC-IBD at eight years after IBD diagnosis, and further surveillance is based on the results together with other risk factors ${ }^{[2]}$.

In PSC-IBD, surveillance colonoscopy every or every other year is recommended independent of IBD duration ${ }^{[93]}$. The evidence for the recommendation to start colonoscopy surveillance at onset of PSC diagnosis is scarce ${ }^{[93-96]}$. To what extent heredity, active inflammation, and inflammatory polyps may contribute to CRC risk in PSC-IBD, as well as their potential impact on the surveillance strategy, has not yet been evaluated.

\section{Chemoprevention}

Large studies evaluating chemopreventive treatment for cancer in PSC are lacking.

In a Cochrane report from $2017^{[97]}, 22$ randomized controlled trials (RCTs) in PSC were evaluated with the primary aim to investigate the effect of different drugs on survival. Cancer was analyzed as a secondary outcome. No evidence of beneficial effect was found for any of the studied drugs (including ursodeoxycholic acid, various immunosuppressants, and antibiotics). 
Two well-studied agents sought to be preventive of several cancer forms are aspirin and statins. Reduced risks of CRC and CCA in general have been associated to aspirin exposure ${ }^{[98-100]}$, although studies analyzing dose and time response are still lacking. There is also evidence for aspirin reducing mortality when used as an adjuvant treatment for $\mathrm{CRC}$ and $\mathrm{CCA}^{[101,102]}$. In PSC, one study has been performed showing borderline significance favoring aspirin as chemoprotective for $\mathrm{CCA}^{[103]}$. Statins have not been proven to be risk reducing for CRC in general ${ }^{[104]}$, but evidence is rising for the risk-reducing effect in $\mathrm{CCA}^{[105-107]}$, although well-designed RCTs needs to confirm this association before recommendations to a risk population can be made. There is an ongoing randomized controlled trial investigating the efficacy of simvastatin in PSC with the composite endpoint transplantation, CCA, and variceal bleeding (clinicaltrials.gov: NCT04133792).

Chemopreventive treatment in IBD has been evaluated in several studies with somewhat conflicting results. Some studies point towards a protective effect of 5-aminosalicylates in UC patients ${ }^{[0,108-110]}$, whereas one population-based study and two meta-analyses do not ${ }^{[111-113]}$. Considering the elevated risk of CRC in PSCIBD, the underestimation of inflammatory activity and the beneficial safety profile, 5-ASA is usually recommended in all PSC-IBD patients, despite the lack of robust evidence ${ }^{[111-113]}$. Ursodeoxycholic acid (UDCA) has been evaluated as a potential chemopreventive treatment for CRC in PSC-IBD. Early, small studies indicated a cancer protective effect ${ }^{[14,115]}$, whereas more recent studies have failed to show a beneficiary effect ${ }^{[3,116,117]}$. In a large meta-analysis of eight studies (including three RCTs), no convincing beneficial effect of UDCA for prevention of CRC was found ${ }^{[118]}$. On the contrary, a high dose of UDCA (28$30 \mathrm{mg} / \mathrm{kg} /$ day) has been associated with an increased risk of CRC ${ }^{[119]}$. Treatment with UDCA should therefore be governed by the practice for treatment of the liver disease, and UDCA is not recommended as chemoprevention for CRC.

\section{FUTURE PERSPECTIVES}

Albeit convenient for health professionals to use one surveillance template for all patients, the future will likely demand a more individualized strategy. Considering the poor prognosis of advanced CCA and GBC, strategies for chemoprevention, earlier detection, and better treatment are needed. The identification of high-risk patients, who should be identified with new biomarkers/biomarker profiles, is important in future research. The possibility to develop and validate such markers are hampered by few cases, and large collaborative studies are required. There is ongoing research on different markers in serum, among other studies on specific RNA profiles in extracellular vesicles ${ }^{[120]}$ and miRNAs ${ }^{[121]}$, as well as proteomics, lipidomics, and metabolomics both in serum and bile ${ }^{[122]}$. Next-generation sequencing on brush samples at $\mathrm{ERCP}^{[123]}$ may also increase the diagnostic accuracy and be of importance for chemotherapy guidance.

Development and broad implementation of diagnostic means for differentiation between benign and malignant bile duct epithelium with, for example, high-quality MRI, cholangioscopy with targeted biopsies, and genetic markers are additionally important. It should also be pointed out that the lack of treatment to halt the disease progression to cirrhosis is a major future challenge. Identifying drugs delaying the progression of PSC could also potentially reduce the cancer risk in PSC.

The high risk of colorectal cancer in PSC-IBD warrants focus on better understanding of this specific phenotype of IBD and what mechanisms are involved in the malignant process. The impact of longstanding inflammation, inflammatory polyps, and heredity of CRC in PSC-IBD should further be studied and considered in future surveillance strategies for PSC-IBD. The role of the systematic use of chromoendoscopy remains to be established in PSC-IBD as well as different virtual chromoendoscopic techniques such as NBI (narrow band imaging), FICE (Flexible Spectral Imaging Color Enhancement), and i-scans. 


\section{DECLARATIONS}

\section{Authors' contributions}

Made substantial contributions to conception and design of the study and performed data analysis and interpretation: Lundberg Båve A, Bergquist A

\section{Availability of data and materials}

Not applicable.

\section{Financial support and sponsorship}

This work was supported by Swedish Cancer Society, Stockholm County Council, and the Cancer Research Funds of Radiumhemmet.

\section{Conflicts of interest}

Both authors declared that there are no conflicts of interest.

\section{Ethical approval and consent to participate}

Not applicable.

\section{Consent for publication}

Not applicable.

\section{Copyright}

(c) The Authors 2021.

\section{REFERENCES}

1. Boonstra K, Weersma RK, van Erpecum KJ, et al; EpiPSCPBC Study Group. Population-based epidemiology, malignancy risk, and outcome of primary sclerosing cholangitis. Hepatology 2013;58:2045-55. DOI PubMed

2. Barner-Rasmussen N, Pukkala E, Jussila A, Färkkilä M. Epidemiology, risk of malignancy and patient survival in primary sclerosing cholangitis: a population-based study in Finland. Scand J Gastroenterol 2020;55:74-81. DOI PubMed

3. Liang H, Manne S, Shick J, Lissoos T, Dolin P. Incidence, prevalence, and natural history of primary sclerosing cholangitis in the United Kingdom. Medicine (Baltimore) 2017;96:e7116. DOI PubMed PMC

4. Valle MB, Björnsson E, Lindkvist B. Mortality and cancer risk related to primary sclerosing cholangitis in a Swedish populationbased cohort. Liver Int 2012;32:441-8. DOI PubMed

5. Vries AB, Janse M, Blokzijl H, Weersma RK. Distinctive inflammatory bowel disease phenotype in primary sclerosing cholangitis. World J Gastroenterol 2015;21:1956-71. DOI PubMed PMC

6. Loftus EV Jr, Harewood GC, Loftus CG, et al. PSC-IBD: a unique form of inflammatory bowel disease associated with primary sclerosing cholangitis. Gut 2005;54:91-6. DOI PubMed PMC

7. Jørgensen KK, Grzyb K, Lundin KE, et al. Inflammatory bowel disease in patients with primary sclerosing cholangitis: clinical characterization in liver transplanted and nontransplanted patients. Inflamm Bowel Dis 2012;18:536-45. DOI PubMed

8. Rizvi S, Eaton JE, Gores GJ. Primary sclerosing cholangitis as a premalignant biliary tract disease: surveillance and management. Clin Gastroenterol Hepatol 2015;13:2152-65. DOI PubMed PMC

9. Folseraas T, Boberg KM. Cancer risk and surveillance in primary sclerosing cholangitis. Clin Liver Dis 2016;20:79-98. DOI PubMed

10. Tischendorf JJ, Hecker H, Krüger M, Manns MP, Meier PN. Characterization, outcome, and prognosis in 273 patients with primary sclerosing cholangitis: a single center study. Am J Gastroenterol 2007;102:107-14. DOI PubMed

11. Bergquist A, Ekbom A, Olsson R, et al. Hepatic and extrahepatic malignancies in primary sclerosing cholangitis. J Hepatol 2002;36:321-7. DOI PubMed

12. Ananthakrishnan AN, Cagan A, Gainer VS, et al. Mortality and extraintestinal cancers in patients with primary sclerosing cholangitis and inflammatory bowel disease. J Crohns Colitis 2014;8:956-63. DOI PubMed PMC

13. Trivedi PJ, Crothers H, Mytton J, et al. Effects of primary sclerosing cholangitis on risks of cancer and death in people with inflammatory bowel disease, based on sex, race, and age. Gastroenterology 2020;159:915-28. DOI PubMed

14. Takakura WR, Tabibian JH, Bowlus CL. The evolution of natural history of primary sclerosing cholangitis. Curr Opin Gastroenterol 2017;33:71-7. DOI PubMed PMC

15. Gores GJ, Nagorney DM, Rosen CB. Cholangiocarcinoma: is transplantation an option? J Hepatol 2007;47:455-9. DOI PubMed

16. Rosen CB, Heimbach JK, Gores GJ. Surgery for cholangiocarcinoma: the role of liver transplantation. HPB (Oxford) 2008;10:186-9. 
DOI PubMed PMC

17. Björnsson E, Boberg KM, Cullen S, et al. Patients with small duct primary sclerosing cholangitis have a favourable long term prognosis. Gut 2002;51:731-5. DOI PubMed PMC

18. Floreani A, Rizzotto ER, Ferrara F, et al. Clinical course and outcome of autoimmune hepatitis/primary sclerosing cholangitis overlap syndrome. Am J Gastroenterol 2005;100:1516-22. DOI PubMed

19. Weismüller TJ, Trivedi PJ, Bergquist A, et al; International PSC Study Group. Patient age, sex, and inflammatory bowel disease phenotype associate with course of primary sclerosing cholangitis. Gastroenterology 2017;152:1975-84.e8. DOI PubMed PMC

20. Bowlus CL, Lim JK, Lindor KD. AGA clinical practice update on surveillance for hepatobiliary cancers in patients with primary sclerosing cholangitis: expert review. Clin Gastroenterol Hepatol 2019;17:2416-22. DOI PubMed

21. Lundberg Båve A, Bergquist, von Seth, et al. Cancer risk in primary sclerosing cholangitis. ueg journal 2019;7:153.

22. Chapman RW, Williamson KD. Are dominant strictures in primary sclerosing cholangitis a risk factor for cholangiocarcinoma? Curr Hepatol Rep 2017;16:124-9. DOI PubMed PMC

23. Rudolph G, Gotthardt D, Kloeters-Plachky P, Rost D, Kulaksiz H, Stiehl A. In PSC with dominant bile duct stenosis, IBD is associated with an increase of carcinomas and reduced survival. J Hepatol 2010;53:313-7. DOI PubMed

24. Bergquist A, Glaumann H, Persson B, Broomé U. Risk factors and clinical presentation of hepatobiliary carcinoma in patients with primary sclerosing cholangitis: a case-control study. Hepatology 1998;27:311-6. DOI PubMed

25. Chalasani N, Baluyut A, Ismail A, et al. Cholangiocarcinoma in patients with primary sclerosing cholangitis: a multicenter casecontrol study. Hepatology 2000;31:7-11. DOI PubMed

26. Broomé U, Löfberg R, Veress B, Eriksson LS. Primary sclerosing cholangitis and ulcerative colitis: evidence for increased neoplastic potential. Hepatology 1995;22:1404-8. DOI PubMed

27. Gulamhusein AF, Eaton JE, Tabibian JH, Atkinson EJ, Juran BD, Lazaridis KN. Duration of inflammatory bowel disease is associated with increased risk of cholangiocarcinoma in patients with primary sclerosing cholangitis and IBD. Am J Gastroenterol 2016;111:705-11. DOI PubMed PMC

28. Broomé U, Olsson R, Lööf L, et al. Natural history and prognostic factors in 305 Swedish patients with primary sclerosing cholangitis. Gut 1996;38:610-5. DOI PubMed PMC

29. Ahrendt SA, Pitt HA, Nakeeb A, et al. Diagnosis and management of cholangiocarcinoma in primary sclerosing cholangitis. $J$ Gastrointest Surg 1999;3:357-67; discussion 367. DOI PubMed

30. Chapman MH, Webster GJ, Bannoo S, Johnson GJ, Wittmann J, Pereira SP. Cholangiocarcinoma and dominant strictures in patients with primary sclerosing cholangitis: a 25-year single-centre experience. Eur J Gastroenterol Hepatol 2012;24:1051-8. DOI PubMed PMC

31. Kornfeld D, Ekbom A, Ihre T. Survival and risk of cholangiocarcinoma in patients with primary sclerosing cholangitis. A populationbased study. Scand J Gastroenterol 1997;32:1042-5. DOI PubMed

32. Bakhshi Z, Hilscher MB, Gores GJ, et al. An update on primary sclerosing cholangitis epidemiology, outcomes and quantification of alkaline phosphatase variability in a population-based cohort. $J$ Gastroenterol 2020;55:523-32. DOI PubMed PMC

33. Burak K, Angulo P, Pasha TM, Egan K, Petz J, Lindor KD. Incidence and risk factors for cholangiocarcinoma in primary sclerosing cholangitis. Am J Gastroenterol 2004;99:523-6. DOI PubMed

34. Fevery J, Verslype C, Lai G, Aerts R, Van Steenbergen W. Incidence, diagnosis, and therapy of cholangiocarcinoma in patients with primary sclerosing cholangitis. Dig Dis Sci 2007;52:3123-35. DOI PubMed

35. Fevery J, Henckaerts L, Van Oirbeek R, et al. Malignancies and mortality in 200 patients with primary sclerosering cholangitis: a long-term single-centre study. Liver Int 2012;32:214-22. DOI PubMed

36. Said K, Glaumann H, Bergquist A. Gallbladder disease in patients with primary sclerosing cholangitis. J Hepatol 2008;48:598-605. DOI PubMed

37. van Erp LW, Cunningham M, Narasimman M, et al. Risk of gallbladder cancer in patients with primary sclerosing cholangitis and radiographically detected gallbladder polyps. Liver Int 2020;40:382-92. DOI PubMed

38. Buckles DC, Lindor KD, Larusso NF, Petrovic LM, Gores GJ. In primary sclerosing cholangitis, gallbladder polyps are frequently malignant. Am J Gastroenterol 2002;97:1138-42. DOI PubMed

39. Sagvand B, Edwards K, Shen B. Frequency, risk factors, and outcome of gallbladder polyps in patients with primary sclerosing cholangitis: a case-control study. Hepatol Commun 2018;2:1440-5. DOI PubMed PMC

40. Forner A, Reig M, Bruix J. Hepatocellular carcinoma. Lancet 2018;391:1301-14. DOI PubMed

41. Harnois DM, Gores GJ, Ludwig J, Steers JL, Larusso NF, Wiesner RH. Are patients with cirrhotic stage primary sclerosing cholangitis at risk for the development of hepatocellular cancer? J Hepatol 1997;27:512-6. DOI PubMed

42. Zenouzi R, Weismüller TJ, Hübener P, et al. Low risk of hepatocellular carcinoma in patients with primary sclerosing cholangitis with cirrhosis. Clin Gastroenterol Hepatol 2014;12:1733-8. DOI PubMed

43. Ali AH, Tabibian JH, Nasser-Ghodsi N, et al. Surveillance for hepatobiliary cancers in patients with primary sclerosing cholangitis. Hepatology 2018;67:2338-51. DOI PubMed

44. Everhov ÅH, Erichsen R, Sachs MC, et al. Inflammatory bowel disease and pancreatic cancer: a Scandinavian register-based cohort study 1969-2017. Aliment Pharmacol Ther 2020;52:143-54. DOI PubMed

45. Charatcharoenwitthaya P, Enders FB, Halling KC, Lindor KD. Utility of serum tumor markers, imaging, and biliary cytology for detecting cholangiocarcinoma in primary sclerosing cholangitis. Hepatology 2008;48:1106-17. DOI PubMed

46. Razumilava N, Gores GJ, Lindor KD. Cancer surveillance in patients with primary sclerosing cholangitis. Hepatology 2011;54:184252. DOI PubMed PMC 
47. Eaton JE, Welle CL, Bakhshi Z, et al. Early cholangiocarcinoma detection with magnetic resonance imaging versus ultrasound in primary sclerosing cholangitis. Hepatology 2021;73:1868-81. DOI PubMed PMC

48. Boyd S, Vannas M, Jokelainen K, et al. Suspicious brush cytology is an indication for liver transplantation evaluation in primary sclerosing cholangitis. World J Gastroenterol 2017;23:6147-54. DOI PubMed PMC

49. Andersen IM, Fosby B, Boberg KM, et al. Indications and outcomes in liver transplantation in patients with primary sclerosing cholangitis in Norway. Transplant Direct 2015;1:e39. DOI PubMed PMC

50. Majeed A, Castedal M, Arnelo U, Söderdahl G, Bergquist A, Said K. Optimizing the detection of biliary dysplasia in primary sclerosing cholangitis before liver transplantation. Scand J Gastroenterol 2018;53:56-63. DOI PubMed

51. Ramage JK, Donaghy A, Farrant J, Iorns R, Williams R. Serum tumor markers for the diagnosis of cholangiocarcinoma in primary sclerosing cholangitis. Gastroenterology 1995;108:865-9. DOI PubMed

52. Hultcrantz R, Olsson R, Danielsson $\AA$, et al. A 3-year prospective study on serum tumor markers used for detecting cholangiocarcinoma in patients with primary sclerosing cholangitis. J Hepatol 1999;30:669-73. DOI PubMed

53. Sinakos E, Saenger AK, Keach J, Kim WR, Lindor KD. Many patients with primary sclerosing cholangitis and increased serum levels of carbohydrate antigen 19-9 do not have cholangiocarcinoma. Clin Gastroenterol Hepatol 2011;9:434-9.e1. DOI PubMed

54. Venkatesh PG, Navaneethan U, Shen B, McCullough AJ. Increased serum levels of carbohydrate antigen 19-9 and outcomes in primary sclerosing cholangitis patients without cholangiocarcinoma. Dig Dis Sci 2013;58:850-7. DOI PubMed

55. Levy C, Lymp J, Angulo P, Gores GJ, Larusso N, Lindor KD. The value of serum CA 19-9 in predicting cholangiocarcinomas in patients with primary sclerosing cholangitis. Dig Dis Sci 2005;50:1734-40. DOI PubMed

56. Wannhoff A, Brune M, Knierim J, Weiss KH, Rupp C, Gotthardt DN. Longitudinal analysis of CA19-9 reveals individualised normal range and early changes before development of biliary tract cancer in patients with primary sclerosing cholangitis. Aliment Pharmacol Ther 2019;49:769-78. DOI PubMed

57. Wannhoff A, Hov JR, Folseraas T, et al. FUT2 and FUT3 genotype determines CA19-9 cut-off values for detection of cholangiocarcinoma in patients with primary sclerosing cholangitis. J Hepatol 2013;59:1278-84. DOI PubMed

58. Wannhoff A, Rupp C, Friedrich K, et al. Inflammation but not biliary obstruction is associated with carbohydrate antigen 19-9 levels in patients with primary sclerosing cholangitis. Clin Gastroenterol Hepatol 2015;13:2372-9. DOI PubMed

59. Wiles R, Thoeni RF, Barbu ST, et al. Management and follow-up of gallbladder polyps : joint guidelines between the European Society of Gastrointestinal and Abdominal Radiology (ESGAR), European Association for Endoscopic Surgery and other Interventional Techniques (EAES), International Society of Digestive Surgery - European Federation (EFISDS) and European Society of Gastrointestinal Endoscopy (ESGE). Eur Radiol 2017;27:3856-66. DOI PubMed PMC

60. Lindor KD, Kowdley KV, Harrison ME; American College of Gastroenterology. ACG clinical guideline: primary sclerosing cholangitis. Am J Gastroenterol 2015;110:646-59; quiz 660. DOI PubMed

61. Association for the Study of the Liver. EASL clinical practice guidelines: management of cholestatic liver diseases. $J$ Hepatol 2009;51:237-67. DOI PubMed

62. Krugliak Cleveland N, Rubin DT, Hart J, et al. Patients with ulcerative colitis and primary sclerosing cholangitis frequently have subclinical inflammation in the proximal colon. Clin Gastroenterol Hepatol 2018;16:68-74. DOI PubMed PMC

63. Ricciuto A, Fish J, Carman N, et al. Symptoms do not correlate with findings from colonoscopy in children with inflammatory bowel disease and primary sclerosing cholangitis. Clin Gastroenterol Hepatol 2018;16:1098-1105.e1. DOI PubMed

64. Shah SC, Ten Hove JR, Castaneda D, et al. High risk of advanced colorectal neoplasia in patients with primary sclerosing cholangitis associated with inflammatory bowel disease. Clin Gastroenterol Hepatol 2018;16:1106-1113.e3. DOI PubMed

65. Soetikno RM, Lin OS, Heidenreich PA, Young HS, Blackstone MO. Increased risk of colorectal neoplasia in patients with primary sclerosing cholangitis and ulcerative colitis: a meta-analysis. Gastrointest Endosc 2002;56:48-54. DOI PubMed

66. Zheng HH, Jiang XL. Increased risk of colorectal neoplasia in patients with primary sclerosing cholangitis and inflammatory bowel disease: a meta-analysis of 16 observational studies. Eur J Gastroenterol Hepatol 2016;28:383-90. DOI PubMed

67. Kornfeld D, Ekbom A, Ihre T. Is there an excess risk for colorectal cancer in patients with ulcerative colitis and concomitant primary sclerosing cholangitis? Gut 1997;41:522-5. DOI PubMed PMC

68. Sørensen JØ, Nielsen OH, Andersson M, et al. Inflammatory bowel disease with primary sclerosing cholangitis: a Danish populationbased cohort study 1977-2011. Liver Int 2018;38:532-41. DOI PubMed

69. Sharma P, Montgomery E. Gastrointestinal dysplasia. Pathology 2013;45:273-85. DOI PubMed

70. Card TR, Solaymani-Dodaran M, West J. Incidence and mortality of primary sclerosing cholangitis in the UK: a population-based cohort study. J Hepatol 2008;48:939-44. DOI PubMed

71. Braden B, Halliday J, Aryasingha S, et al. Risk for colorectal neoplasia in patients with colonic Crohn's disease and concomitant primary sclerosing cholangitis. Clin Gastroenterol Hepatol 2012;10:303-8. DOI PubMed

72. Lindström L, Lapidus A, Ost A, Bergquist A. Increased risk of colorectal cancer and dysplasia in patients with Crohn's colitis and primary sclerosing cholangitis. Dis Colon Rectum 2011;54:1392-7. DOI PubMed

73. Navaneethan U, Rai T, Venkatesh PG, Kiran RP. Primary sclerosing cholangitis and the risk of colon neoplasia in patients with Crohn's colitis. Gastroenterol Rep (Oxf) 2016;4:226-31. DOI PubMed PMC

74. Jess T, Loftus EV Jr, Velayos FS, et al. Risk factors for colorectal neoplasia in inflammatory bowel disease: a nested case-control study from Copenhagen county, Denmark and Olmsted county, Minnesota. Am J Gastroenterol 2007;102:829-36. DOI PubMed

75. Shetty K, Rybicki L, Brzezinski A, Carey WD, Lashner BA. The risk for cancer or dysplasia in ulcerative colitis patients with primary sclerosing cholangitis. Am J Gastroenterol 1999;94:1643-9. DOI PubMed

76. Lundqvist K, Broomé U. Differences in colonic disease activity in patients with ulcerative colitis with and without primary sclerosing 
cholangitis: a case control study. Dis Colon Rectum 1997;40:451-6. DOI PubMed

77. Moayyeri A, Daryani NE, Bahrami H, Haghpanah B, Nayyer-Habibi A, Sadatsafavi M. Clinical course of ulcerative colitis in patients with and without primary sclerosing cholangitis. J Gastroenterol Hepatol 2005;20:366-70. DOI PubMed

78. Barrasa JI, Olmo N, Lizarbe MA, Turnay J. Bile acids in the colon, from healthy to cytotoxic molecules. Toxicol In Vitro 2013;27:964-77. DOI PubMed

79. Sabino J, Vieira-Silva S, Machiels K, et al. Primary sclerosing cholangitis is characterised by intestinal dysbiosis independent from IBD. Gut 2016;65:1681-9. DOI PubMed PMC

80. Dvorchik I, Subotin M, Demetris AJ, et al. Effect of liver transplantation on inflammatory bowel disease in patients with primary sclerosing cholangitis. Hepatology 2002;35:380-4. DOI PubMed PMC

81. Goss JA, Shackleton CR, Farmer DG, et al. Orthotopic liver transplantation for primary sclerosing cholangitis. A 12-year single center experience. Ann Surg 1997;225:472-81; discussion 481. DOI PubMed PMC

82. Vera A, Gunson BK, Ussatoff V, et al. Colorectal cancer in patients with inflammatory bowel disease after liver transplantation for primary sclerosing cholangitis. Transplantation 2003;75:1983-8. DOI PubMed

83. Jørgensen KK, Lindström L, Cvancarova M, et al. Colorectal neoplasia in patients with primary sclerosing cholangitis undergoing liver transplantation: a Nordic multicenter study. Scand J Gastroenterol 2012;47:1021-9. DOI PubMed

84. Singh S, Edakkanambeth Varayil J, Loftus EV Jr, Talwalkar JA. Incidence of colorectal cancer after liver transplantation for primary sclerosing cholangitis: a systematic review and meta-analysis. Liver Transpl 2013;19:1361-9. DOI PubMed

85. Lutgens M, Vermeire S, Van Oijen M, et al; Dutch Initiative on Crohn and Colitis. A rule for determining risk of colorectal cancer in patients with inflammatory bowel disease. Clin Gastroenterol Hepatol 2015;13:148-54.e1. DOI PubMed

86. Hovde Ø, Høivik ML, Henriksen M, Solberg IC, Småstuen MC, Moum BA. Malignancies in patients with inflammatory bowel disease: results from 20 years of follow-up in the IBSEN study. J Crohns Colitis 2017;11:571-7. DOI PubMed

87. Askling J, Dickman PW, Karlén P, et al. Family history as a risk factor for colorectal cancer in inflammatory bowel disease. Gastroenterology 2001;120:1356-62. DOI PubMed

88. Rutter MD, Saunders BP, Wilkinson KH, et al. Cancer surveillance in longstanding ulcerative colitis: endoscopic appearances help predict cancer risk. Gut 2004;53:1813-6. DOI PubMed PMC

89. Rutter M, Saunders B, Wilkinson K, et al. Severity of inflammation is a risk factor for colorectal neoplasia in ulcerative colitis. Gastroenterology 2004;126:451-9. DOI PubMed

90. Velayos FS, Loftus EV Jr, Jess T, et al. Predictive and protective factors associated with colorectal cancer in ulcerative colitis: a casecontrol study. Gastroenterology 2006;130:1941-9. DOI PubMed

91. Gumaste V, Sachar DB, Greenstein AJ. Benign and malignant colorectal strictures in ulcerative colitis. Gut 1992;33:938-41. DOI PubMed PMC

92. Magro F, Gionchetti P, Eliakim R, et al; European Crohn's and Colitis Organisation [ECCO]. Third European evidence-based consensus on diagnosis and management of Ulcerative Colitis. Part 1: definitions, diagnosis, extra-intestinal manifestations, pregnancy, cancer surveillance, surgery, and Ileo-anal pouch disorders. J Crohns Colitis 2017;11:649-70. DOI PubMed

93. Bhat P, Aabakken L. Role of endoscopy in primary sclerosing cholangitis. Clin Endosc 2021;54:193-201. DOI PubMed PMC

94. Society of Gastrointestinal Endoscopy; European Association for the Study of the Liver; Electronic address: easloffice@easloffice.eu; European Association for the Study of the Liver. Role of endoscopy in primary sclerosing cholangitis: European society of Gastrointestinal Endoscopy (ESGE) and European Association for the study of the Liver (EASL) clinical guideline. J Hepatol 2017;66:1265-81. DOI PubMed

95. Association for the Study of the Liver. EASL Clinical Practice Guidelines: management of cholestatic liver diseases. $J$ Hepatol 2009;51:237-67. DOI PubMed

96. Chapman MH, Thorburn D, Hirschfield GM, et al. British Society of Gastroenterology and UK-PSC guidelines for the diagnosis and management of primary sclerosing cholangitis. Gut 2019;68:1356-78. DOI PubMed PMC

97. Saffioti F, Gurusamy KS, Hawkins N, et al. Pharmacological interventions for primary sclerosing cholangitis: an attempted network meta-analysis. Cochrane Database Syst Rev 2017;3:CD011343. DOI PubMed PMC

98. Choi J, Ghoz HM, Peeraphatdit T, et al. Aspirin use and the risk of cholangiocarcinoma. Hepatology 2016;64:785-96. DOI PubMed PMC

99. Altaii H, Al-Kindi SG, Oliveira GH, Yaqoob Z, Romero-Marrero C. Aspirin use and risk of cholangiocarcinoma: external validation with big data. Hepatology 2017;65:1421-2. DOI PubMed

100. Rothwell PM, Wilson M, Elwin C, et al. Long-term effect of aspirin on colorectal cancer incidence and mortality: 20-year follow-up of five randomised trials. Lancet 2010;376:1741-50. DOI PubMed

101. Jackson SS, Pfeiffer RM, Liu Z, et al. Association between aspirin use and biliary tract cancer survival. JAMA Oncol 2019;5:1802-4. DOI PubMed PMC

102. Restivo A, Cocco IM, Casula G, et al. Aspirin as a neoadjuvant agent during preoperative chemoradiation for rectal cancer. $\mathrm{Br} J$ Cancer 2015;113:1133-9. DOI PubMed PMC

103. Abushamma S, Esfeh JM. Aspirin and statin use in preventing cholangiocarcinoma (CCA) in patients with primary sclerosing cholangitis (PSC): 866. Am J Gastroenterol 2018;113:S482-3. DOI

104. Bonovas S, Filioussi K, Flordellis CS, Sitaras NM. Statins and the risk of colorectal cancer: a meta-analysis of 18 studies involving more than 1.5 million patients. J Clin Oncol 2007;25:3462-8. DOI PubMed

105. Bonilla LM, Schleck C, Harmsen W, et al. 3437 Associations of aspirin, non-aspirin NSAIDs, statins, and metformin with risk of biliary cancer: a Swedish population-based cohort study. J Clin Trans Sci 2019;3:35-35. DOI 
106. Liu Z, Alsaggaf R, McGlynn KA, et al. Statin use and reduced risk of biliary tract cancers in the UK Clinical Practice Research Datalink. Gut 2019;68:1458-64. DOI PubMed PMC

107. Lavu S, Therneau TM, Harmsen WS, et al. Effect of statins on the risk of extrahepatic cholangiocarcinoma. Hepatology 2020;72:1298-309. DOI PubMed PMC

108. Bonovas S, Fiorino G, Lytras T, Nikolopoulos G, Peyrin-Biroulet L, Danese S. Systematic review with meta-analysis: use of 5aminosalicylates and risk of colorectal neoplasia in patients with inflammatory bowel disease. Aliment Pharmacol Ther 2017;45:1179-92. DOI PubMed

109. O'Connor A, Packey CD, Akbari M, Moss AC. Mesalamine, but not sulfasalazine, reduces the risk of colorectal neoplasia in patients with inflammatory bowel disease: an agent-specific systematic review and meta-analysis. Inflamm Bowel Dis 2015;21:2562-9. DOI PubMed

110. Zhao LN, Li JY, Yu T, Chen GC, Yuan YH, Chen QK. 5-Aminosalicylates reduce the risk of colorectal neoplasia in patients with ulcerative colitis: an updated meta-analysis. PLoS One 2014;9:e94208. DOI PubMed PMC

111. Nguyen GC, Gulamhusein A, Bernstein CN. 5-aminosalicylic acid is not protective against colorectal cancer in inflammatory bowel disease: a meta-analysis of non-referral populations. Am J Gastroenterol 2012;107:1298-304; quiz 1297, 1305. DOI PubMed

112. Jess T, Lopez A, Andersson M, Beaugerie L, Peyrin-Biroulet L. Thiopurines and risk of colorectal neoplasia in patients with inflammatory bowel disease: a meta-analysis. Clin Gastroenterol Hepatol 2014;12:1793-1800.e1. DOI PubMed

113. Terdiman JP, Steinbuch M, Blumentals WA, Ullman TA, Rubin DT. 5-Aminosalicylic acid therapy and the risk of colorectal cancer among patients with inflammatory bowel disease. Inflamm Bowel Dis 2007;13:367-71. DOI PubMed

114. Tung BY, Emond MJ, Haggitt RC, et al. Ursodiol use is associated with lower prevalence of colonic neoplasia in patients with ulcerative colitis and primary sclerosing cholangitis. Ann Intern Med 2001;134:89-95. DOI PubMed

115. Pardi DS, Loftus EV Jr, Kremers WK, Keach J, Lindor KD. Ursodeoxycholic acid as a chemopreventive agent in patients with ulcerative colitis and primary sclerosing cholangitis. Gastroenterology 2003;124:889-93. DOI PubMed

116. Lindström L, Boberg KM, Wikman O, et al. High dose ursodeoxycholic acid in primary sclerosing cholangitis does not prevent colorectal neoplasia. Aliment Pharmacol Ther 2012;35:451-7. DOI PubMed

117. Wolf JM, Rybicki LA, Lashner BA. The impact of ursodeoxycholic acid on cancer, dysplasia and mortality in ulcerative colitis patients with primary sclerosing cholangitis. Aliment Pharmacol Ther 2005;22:783-8. DOI PubMed

118. Singh S, Khanna S, Pardi DS, Loftus EV Jr, Talwalkar JA. Effect of ursodeoxycholic acid use on the risk of colorectal neoplasia in patients with primary sclerosing cholangitis and inflammatory bowel disease: a systematic review and meta-analysis. Inflamm Bowel Dis 2013;19:1631-8. DOI PubMed

119. Eaton JE, Silveira MG, Pardi DS, et al. High-dose ursodeoxycholic acid is associated with the development of colorectal neoplasia in patients with ulcerative colitis and primary sclerosing cholangitis. Am J Gastroenterol 2011;106:1638-45. DOI PubMed PMC

120. Lapitz A, Arbelaiz A, O'Rourke CJ, et al. Patients with cholangiocarcinoma present specific RNA profiles in serum and urine extracellular vesicles mirroring the tumor expression: novel liquid biopsy biomarkers for disease diagnosis. Cells 2020;9:721. DOI PubMed PMC

121. Loosen SH, Lurje G, Wiltberger G, et al. Serum levels of miR-29, miR-122, miR-155 and miR-192 are elevated in patients with cholangiocarcinoma. PLoS One 2019;14:e0210944. DOI PubMed PMC

122. Wannhoff A, Gotthardt DN. Recent developments in the research on biomarkers of cholangiocarcinoma in primary sclerosing cholangitis. Clin Res Hepatol Gastroenterol 2019;43:236-43. DOI PubMed

123. Singhi $\mathrm{AD}$, Nikiforova $\mathrm{MN}$, Chennat $\mathrm{J}$, et al. Integrating next-generation sequencing to endoscopic retrograde cholangiopancreatography (ERCP)-obtained biliary specimens improves the detection and management of patients with malignant bile duct strictures. Gut 2020;69:52-61. DOI PubMed PMC

124. Boberg KM, Bergquist A, Mitchell S, et al. Cholangiocarcinoma in primary sclerosing cholangitis: risk factors and clinical presentation. Scand J Gastroenterol 2002;37:1205-11. DOI PubMed

125. Morris-Stiff G, Bhati C, Olliff S, et al. Cholangiocarcinoma complicating primary sclerosing cholangitis: a 24-year experience. Dig Surg 2008;25:126-32. DOI PubMed

126. Claessen MM, Vleggaar FP, Tytgat KM, Siersema PD, van Buuren HR. High lifetime risk of cancer in primary sclerosing cholangitis. J Hepatol 2009;50:158-64. DOI PubMed

127. McGee EE, Castro FA, Engels EA, et al. Associations between autoimmune conditions and hepatobiliary cancer risk among elderly US adults. Int $J$ Cancer 2019;144:707-17. DOI PubMed

128. Wiesner RH, Grambsch PM, Dickson ER, et al. Primary sclerosing cholangitis: natural history, prognostic factors and survival analysis. Hepatology 1989;10:430-6. DOI PubMed

129. Farrant J, Hayllar KM, Wilkinson ML, et al. Natural history and prognostic variables in primary sclerosing cholangitis. Gastroenterology 1991;100:1710-7. DOI PubMed

130. Nashan B, Schlitt HJ, Tusch G, et al. Biliary malignancies in primary sclerosing cholangitis: timing for liver transplantation. Hepatology 1996;23:1105-11. DOI PubMed

131. Jess T, Simonsen J, Jørgensen KT, Pedersen BV, Nielsen NM, Frisch M. Decreasing risk of colorectal cancer in patients with inflammatory bowel disease over 30 years. Gastroenterology 2012;143:375-81.e1; quiz e13. DOI PubMed

132. Guerra I, Bujanda L, Castro J, et al; Spanish GETECCU group (ENEIDA Project). Clinical characteristics, associated malignancies and management of primary sclerosing cholangitis in inflammatory bowel disease patients: a multicentre retrospective cohort study. $J$ Crohns Colitis 2019;13:1492-500. DOI PubMed

133. Sokol H, Cosnes J, Chazouilleres O, et al. Disease activity and cancer risk in inflammatory bowel disease associated with primary 
sclerosing cholangitis. World J Gastroenterol 2008;14:3497-503. DOI PubMed PMC

134. Terg R, Sambuelli A, Coronel E, et al. Prevalence of primary sclerosing cholangitis in patients with ulcerative colitis and the risk of developing malignancies. A large prospective study. Acta Gastroenterol Latinoam 2008;38:26-33. PubMed 